\title{
Osteogenic Cells on Bio-Inspired Materials for Bone Tissue Engineering
}

\author{
B. VAGASKÁ ${ }^{1}$, L. BAČÁKOVÁ ${ }^{1}$, E. FILOVÁ ${ }^{1}$, K. BALÍK ${ }^{2}$ \\ ${ }^{1}$ Department of Growth and Differentiation of Cell Populations, Institute of Physiology, Academy \\ of Sciences of the Czech Republic, Prague, Czech Republic, ${ }^{2}$ Institute of Rock Structure and \\ Mechanics, Academy of Sciences of the Czech Republic, Prague, Czech Republic
}

Received February 24, 2009

Accepted June 18, 2009

On-line August 12, 2009

\section{Summary}

This article reviews the development of artificial bone substitutes from their older single-phase forms to novel multi-phase composites, mimicking the composition and architecture of natural bone tissue. The new generation of bone implants should be bioactive, i.e. they should induce the desired cellular responses, leading to integration of the material into the natural tissue and stimulating self-healing processes. Therefore, the first part of the review explains the common principles of the cellmaterial interaction and summarizes the strategies how to improve the biocompatibility and bioactivity of the materials by modifying the physico-chemical properties of the material surface, such as surface chemistry, wettability, electrical charge, rigidity, microroughness and especially nanoroughness. The latter has been shown to stimulate preferentially the growth of osteoblasts in comparison with other competitive cell types, such as fibroblasts, which could prevent fibrous tissue formation upon implantation. The second more specialized part of the review deals with materials suitable for bone contact and substitution, particularly novel polymer-based composites reinforced with fibres or inorganic particles and containing bioactive components, such as crystals of hydroxyapatite or other calcium phosphates, synthetic ligands for cell adhesion receptors or growth factors. Moreover, if they are degradable, they can be gradually replaced with a regenerating tissue.

\section{Key words}

Multi-phase composites • Nanoroughness • Osteoblasts • Bone implants • Bioartificial bone

\section{Corresponding author}

Lucie Bačáková, Dept. of Growth and Differentiation of Cell Populations, Institute of Physiology, Academy of Sciences of the Czech Republic, Videnska 1083, 14220 Prague 4, Czech Republic. Tel.: +420 29644 3743; Fax: +420 241062488. E-mail: lucy@biomed.cas.cz

\section{Introduction}

Biomaterial science and tissue engineering have developed as new and independent interdisciplinary scientific fields in response to the rising demand for replacements of damaged tissue in the growing and aging population.

In the case of bone tissue loss as a result of bone diseases or traumatic damage, several strategies are applied. Currently, the most widely used are autologous transplantations, using bone grafts from the same patient. However, this has several serious disadvantages, for example the patient is subjected to an additional surgical procedure, as well as prolonged rehabilitation and healing time, increased pain and risk of infection (Mata et al. 2002); but most importantly the amount of available material is limited as the patient's bone tissue is basically being damaged at another site. Allogenic or xenogenic grafts or materials are in general unsuitable, because of the possible immune response and subsequent rejection, as well as the possibility of disease transmission. Therefore, great attention is being paid to the 
development of artificial materials that could possibly replace and substitute the damaged or lost bone tissue.

Apart from the mechanical properties that are imposed on these implanted artificial materials, or biomaterials, the main requirement is their biocompatibility. This means they should be accepted by the surrounding tissues and by the body as a whole. In other words, the materials should be non-toxic, nonimmunogenic and non-carcinogenic (Park and Bronzino 2003).

During the history of biomaterial engineering, a range of approaches has been applied. The earliest so-called first-generation materials were designed as bioinert. The main objective was to create a material that would match the mechanical properties of the replaced tissue, and would not allow protein adsorption and cell adhesion, in order to reduce the possible immune response and rejection (Hench and Polak 2002). However, modern advanced materials, sometimes referred to as second-generation biomaterials, are specifically designed to be "bioactive". This means they should elicit specific desired cellular responses, like cell adhesion, proliferation and differentiation into a specific cell type, e.g., bone cells that will form a new bone tissue and thus integrate the implant strongly into the surrounding natural tissue. The reaction of the cells should be controllable by the physical and chemical properties of the material surface (Hench and Polak 2002, for a review see Bačáková et al. 2004a).

One of the most advanced strategies in recent research in tissue engineering is the construction of 3dimensional porous scaffolds made of resorbable materials, especially polymers. These 3-dimensional porous scaffolds should be seeded with the patient's own cells or even stem cells, e.g., those derived from the bone marrow taken under biopsy from the iliac crest, and then expanded in cell culture conditions. Upon implantation into the body, these hybrid cell-material constructs should gradually replace the missing bone by completely newly formed tissue. The polymeric scaffolds that provide the cells with the necessary support during this self-healing process should be gradually degraded, as they will be continuously replaced by new bone and will eventually disappear completely (Bačáková et al. 2004a). Some authors refer to these materials as third-generation biomaterials, because they will stimulate the specific response of cells at a molecular level, and activate specific gene expression that regulates regeneration and the self-healing process (Hench and Polak 2002).
However, in the case of polymer-based bone constructs, their potential use is still very limited due to their insufficient mechanical properties as load-bearing implants (Kim et al. 2006, Rezwan et al. 2006, Boccaccini and Blaker 2005). These materials need further improvements, e.g. strong mechanically resistant reinforcement with fibrous or particulate component and loading with bioactive molecules which would accelerate the formation of regenerated, mineralized and fully functional bone tissue.

In order to achieve all the desired and regulated cellular responses, the mechanism of cell interaction with the surface of an artificial material must first be well understood. Therefore, the first section of this article reviews the molecular mechanisms of interaction between cells and artificial materials, which is strongly dependent on physical and chemical properties of the material surface. The second part of this review then follows the development of the bone tissue substitutes from their older and usually single-phase forms to advanced bioactive multiphase composites inspired by the composition and architecture of the natural bone tissue.

\section{Common principles of the cell-material interaction}

\section{Protein adsorption and physicochemical properties of the} material surface

Immediately after the biomaterial is implanted into an organism or comes into contact with cell culture environments, protein adsorption to its surface occurs. This happens within seconds, long before the first cells reach the surface. Consequently, cells almost never come into direct contact with the material surface; they rather interact with the layer of adsorbed proteins. This layer mediates the cell adhesion, and also provides signals to the cell through the cell adhesion receptors, mainly integrins. In this way it determines the cellular response to the biomaterial (Thomas et al. 1997).

Proteins that adsorb to the biomaterial surface in contact with physiological fluids (i.e., blood or cell culture media) include fibronectin, vitronectin, fibrinogen, immunoglobulins, albumin and others (Keselowsky et al. 2003). The type, amount and geometrical conformation of adsorbed proteins strongly depend on the physicochemical properties of the material surface, such as its chemical composition, electrical charge, wettability, roughness and topography. On polar and positively charged surfaces, e.g. those endowed with $-\mathrm{OH}$ and $-\mathrm{NH}_{2}$ groups, respectively, 
the spatial conformation of adsorbed fibronectin was more advantageous for binding osteoblast-like MC3T3-E1 cells through their $\alpha_{5} \beta_{1}$ integrin receptors than on non-polar and negatively charged surfaces characterized by $-\mathrm{CH}_{3}$ and COOH groups, respectively (Keselowsky et al. 2003). The presence of polar groups results in wettability of the material surface. It has been well-established that cells preferentially adhere to surfaces with moderate hydrophilicity (Lee et al. 1997, Webb et al. 1998). For example, the highest cell adhesion of Chinese hamster ovary cells (CHO cells) was observed on surfaces with a water drop contact angle of about 50 degrees (Lee et al. 1997). Good cell adhesion has been explained by the adsorption of protein molecules in an appropriate and flexible spatial conformation. This enables protein reorganization and accessibility of the specific ligands by cell adhesion receptors. On the other hand, on extremely hydrophilic surfaces, the cell adhesion-mediating proteins are bound too loosely, so that they do not ensure firm adhesion and spreading of cells on the material surface (for a review see Bačáková et al. 2004a, 2007a). In contrast, hydrophobic surfaces are thought to cause strong adsorption and subsequent denaturation of proteins, which distorts the conformation of cell adhesion receptor-binding domains. In addition, a preferential and strong adsorption of albumin, which acts as non-adhesive for cells, has been reported on these surfaces (Arima and Iwata 2007).

Another important factor influencing the adhesion and subsequent behavior of cells is the material surface roughness and topography. Depending on the scale of irregularities of the material surface, we can distinguish macroroughness (100 $\mu \mathrm{m}$ - milimeters), microroughness (100 nm - $100 \mu \mathrm{m})$, and nanoroughness (less than $100 \mathrm{~nm}$ ), each with its specific influence. Macroroughness seems to be favorable, because it enhances the anchorage of implant into the natural tissue and is not usually felt by the cells, e.g., it does not restrict their attachment and spreading. The micro-scale roughness is more controversial, because the cells can be limited by the material surface topography in their adhesion area (Bačáková et al. 2001, Lossdorfer et al. 2004, Tan and Saltzman 2004). On the other hand, several authors have reported that osteoblasts, grown on microrough surfaces, were stimulated towards differentiation; as shown by their gene expression and higher level of mineralization in comparison with cells growing on smooth surfaces (Schneider et al. 2003, Lossdorfer et al. 2004).
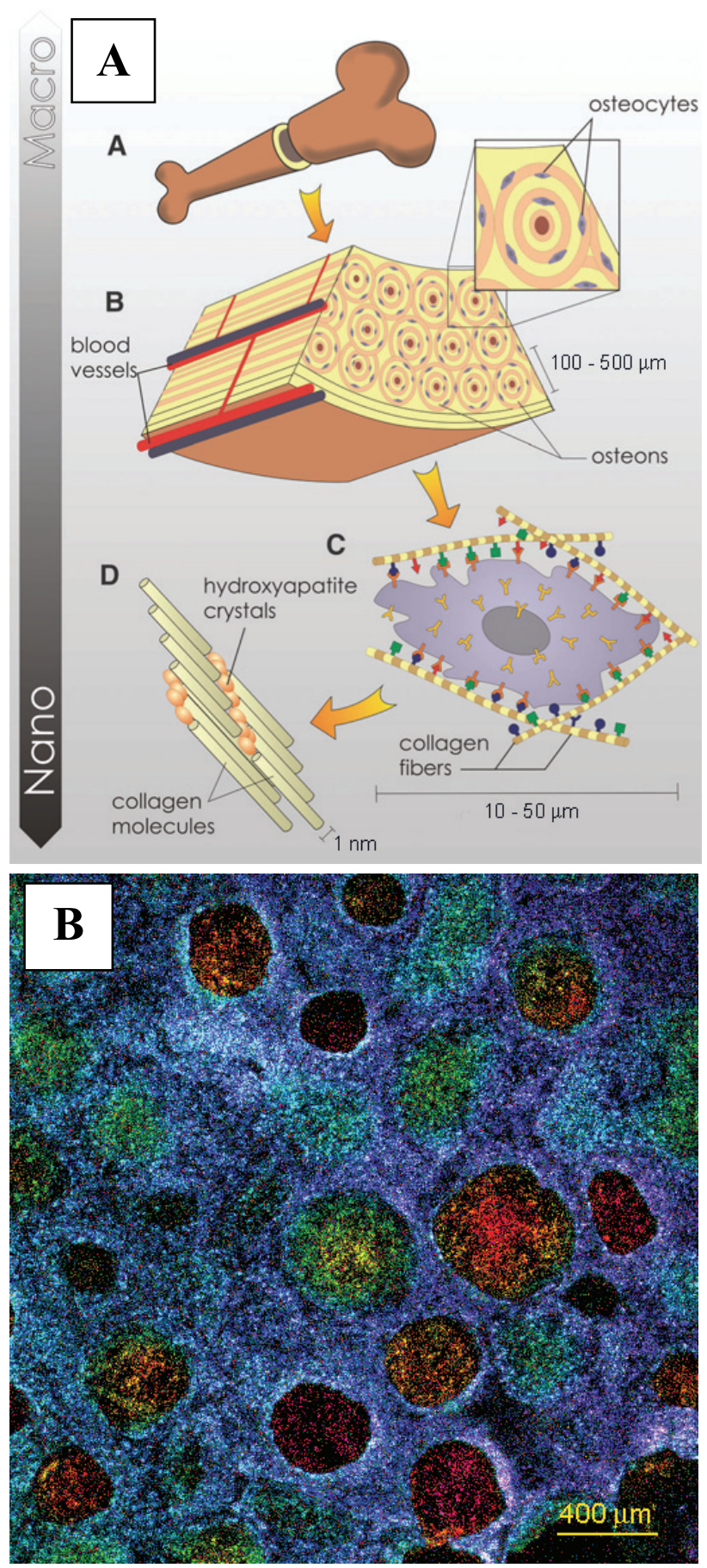

Fig. 1. A. Hierarchical organization of bone on different size scales, including nanoarchitecture of the extracellular matrix (Stevens and George 2005). B. Imitation of this structure by an experimental bioartificial bone construct containing a porous poly(L-lactide-co-glycolide) scaffolds and human osteoblast-like MG 63 cells. The depth of cell ingrowth into the pores is indicated by spectral colors (blue: depth of 0-60 $\mu \mathrm{m}$, green: $80-160 \mu \mathrm{m}$, yellow: $180-220 \mu \mathrm{m}$, orange: $240-300 \mu \mathrm{m}$, red: $320-400 \mu \mathrm{m}$, violet: $420-480 \mu \mathrm{m})$. Day 14 after seeding, cells stained with propidium iodide. Leica TCS SP2 confocal microscope (Pamula et al. 2008). 
This disproportion can be related to the complexity of defining roughness. In the previous studies the most widely used parameter $\mathrm{R}_{\mathrm{a}}$ was applied, which is the average peak to valley height. This measure does not give any record of the type of surface topography; for example distances between the peaks, their sharpness, curvature of valleys etc. (Zhao et al. 2006, Bačáková et al. 2004a). The irregularities also had different shapes, e.g., pyramids, ridges, grooves, round pores, etc. Therefore it is difficult to compare the data of different research groups.

The nanoscale structure of the material surface has been found to have significant positive effects on osteoblast cell response, including initial cell adhesion and subsequent proliferation, and expression of differentiation markers. This finding is not so surprising when we keep in mind that the natural environment of cells, the extracellular matrix (ECM), is also organized in nanodimensions (Fig. 1A). Therefore many of the newly-developed bio-inspired composite materials try to mimic this effect of ECM on cells by constructing nanostructured surfaces.

The beneficial effect of the material surface nanoroughness on cell colonization has been explained by an increased amount an improved spatial conformation of the adsorbed cell adhesion-mediating proteins (Webster et al. 2000, Woo et al. 2003). Moreover, the protein adsorption was selective, showing enhancement for fibronectin and especially for vitronectin. This was attributed to a relatively small size and linear shape of the vitronectin molecule, which can conform to the nanostructure of the material better than bigger and more complicated ECM molecules, e.g., laminin (Webster et al. 2000). Vitronectin is recognized preferentially by osteoblasts in comparison with other osteoblastcompetitive cell types. This selectivity could be highly advantageous, as it could help to prevent the formation of fibrous tissue upon implantation - one of the major problems for all currently used materials - and thus lead to faster integration of the implant.

In addition, several studies have shown that for increased osteoblast adhesion the nanostructure plays a more important role than the surface chemistry. For example, in our earlier study (Bačáková et al. 2007b), a terpolymer of polytetrafluoroethylene, polyvinyldifluoride and polypropylene (PTFE/PVDF/PP) was mixed with 2 to 8 wt. \% carbon nanotubes, which created nano-sized irregularities on the material surface, but did not significantly change the surface hydrophobia (the water drop contact angle about $100^{\circ}$ ). Despite this, the number and spreading of human osteoblast-like cells on the nanotube-modified surfaces was markedly increased (Fig. 2A).

The cells also require a certain level of substrate stiffness for their adhesion. During the process of adhesion and spreading, cells exert traction forces on the underlying substrate and they respond to its compliance. If the surface is too soft, as for example on polyacryalamide gels, it is not able to withstand these forces. The adhering cells are not able to spread: they are rounded, they show no assembly of cytoskeleton and focal adhesions, and consequently undergo apoptosis (Engler et al. 2004). Moreover, a low, medium and high level of the substrate stiffness can direct the differentiation of mesenchymal stem cells towards neuronal, muscle or osteoblast phenotype, respectively (Engler et al. 2006).

\section{Integrins - major cell adhesion receptors}

As mentioned above, the proteins adsorbed on the material surface in an appropriate geometrical conformation are bound by the cell adhesion receptors. The most deeply investigated and systemized group of cell-matrix adhesion receptors are integrins, i.e. heterodimeric transmembrane receptors consisting of non-covalently associated alpha and beta subunits (Hynes 2002). The extracellular domains of integrins bind to the specific amino-acid sequences in the adsorbed protein molecules, e.g. tripeptide sequence of Arg-Gly-Asp (RGD), which is the major motif in many extracellular matrix proteins; including fibronectin, vitronectin (Garcia 2005), type I collagen, osteopontin, bone sialoprotein and thrombospondin (Clover et al. 1992). After binding to their ligands, integrins cluster together in focal adhesions. These large supramolecular complexes contain (a) structural proteins such as talin, vinculin, paxillin and alpha-actinin, (b) signaling molecules, like focal adhesion kinase (FAK), Src and paxilin (Geiger et al. 2001) and (c) growth factor receptors, e.g. bone morphogenetic protein-2 (BMP-2) receptors (Lai and Cheng 2005). Focal adhesions, and particularly integrins, function as transmembrane structural links between the extracellular matrix and actin cytoskeleton inside the cell (Hynes 2002). By providing the anchorage signal, all these structures directly support migration, cell cycle progression and expression of differentiation-related genes (Danen and Sonnenberg 2003).

On the osteoblast surface there are several types of integrin receptors, including $\alpha_{1} \beta_{1}, \alpha_{2} \beta_{1}, \alpha_{3} \beta_{1}, \alpha_{5} \beta_{1}, \alpha_{V} \beta_{3}$, $\alpha_{\mathrm{V}} \beta_{5}$ and $\alpha_{\mathrm{V}} \beta_{8}$ (Clover et al. 1992, Gronthos et al. 1997). Integrins with $\beta_{1}$ chain seem to be the most 

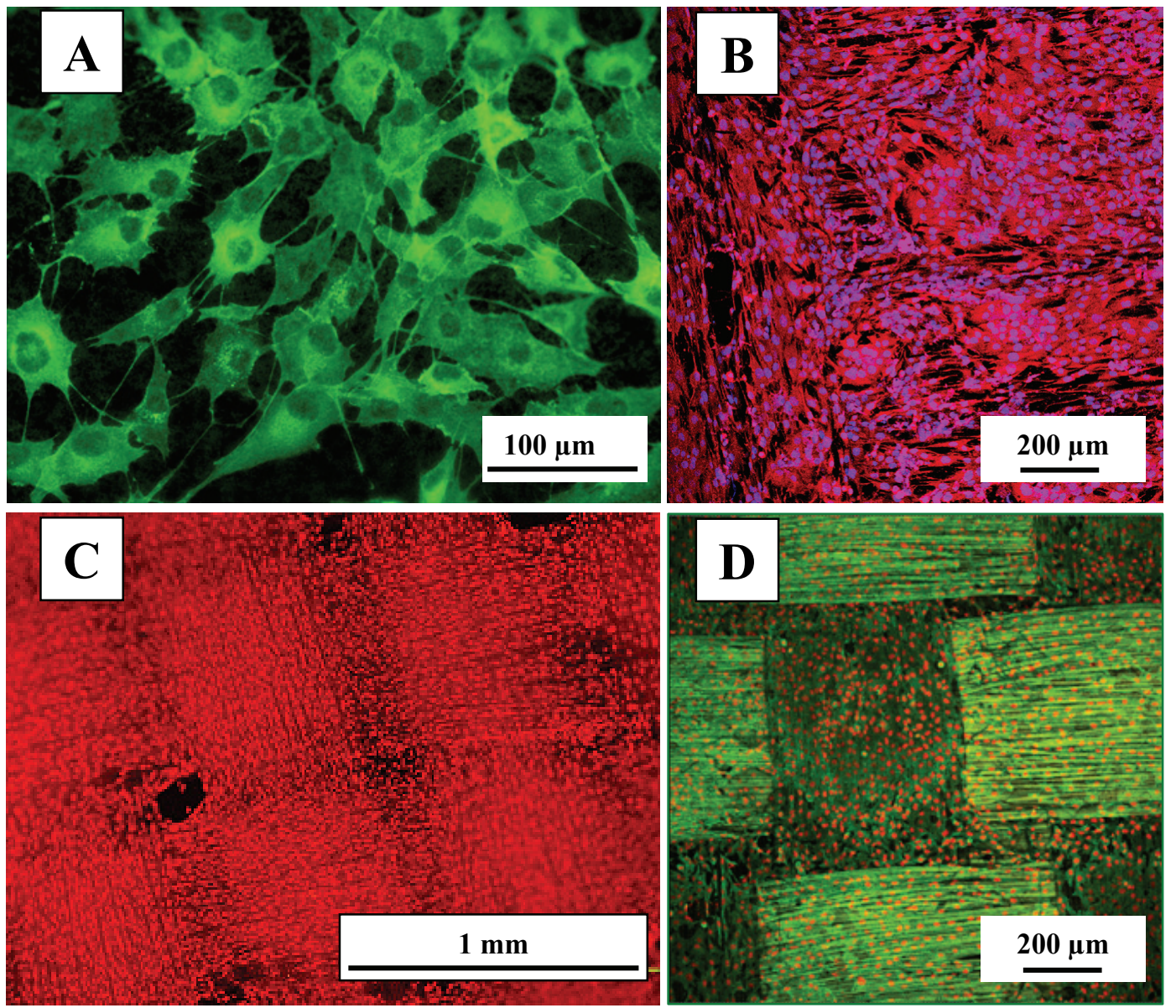

Fig. 2. Human osteoblast-like MG 63 cells in cultures on a terpolymer of polytetrafluoroethylene, polyvinyldifluoride and polypropylene with $4 \mathrm{wt}$ \% of multi-wall carbon nanotubes (A), a composite with the carbon matrix reinforced with carbon fibers (B), aramid fabrics (C) and a composite with polysiloxane matrix reinforced with aramid fabrics (D). A: immunofluorescence of $\beta$-actin, B: Hoechst \# 33342 and Texas Red $C_{2}$ maleimide, $\mathbf{C}$ : propidium iodide, $\mathbf{D}$ : propidium iodide and immunofluorescence of $\beta$-actin. Day 3 (A, D) or day 7 (B, C) after seeding. A, C: Olympus IX 51 microscope, DP 70 digital camera; B, D: Leica TCS SP2 confocal microscope. Bar: $100 \mu \mathrm{m}(\mathbf{A}), 200 \mu \mathrm{m}(\mathbf{B}, \mathbf{D}), 1 \mathrm{~mm}(\mathbf{C})$.

important in osteoblast adhesion to extracellular matrix proteins including: fibronectin, type I collagen, laminin and vitronectin (Gronthos et al. 1997), and play a major role in osteoblast differentiation (Schwartz et al 2007). The osteoblast differentiation is manifested by numerous specific markers, the most followed of them being the synthesis of calcium-binding glycoproteins osteocalcin and osteopontin, collagen I, the activity of alkaline phosphatase and the bone tissue mineralization (Losdorfer et al. 2004, Kesselovski et al. 2005, Lai and Cheng 2005, Sun et al. 2006, Inanc et al. 2007, Dadsetan et al. 2008, Marie 2008, Müller et al. 2008, Satija et al. 2007). Alpha integrins also stimulate the osteoblast differentiation by interacting with receptors for BMP-2 (Lai and Cheng 2005), although $\alpha_{\mathrm{v}} \beta_{3}$ integrins were reported to retard the osteoblast differentiation and bone matrix mineralization, while the cell proliferation was enhanced (Cheng et al. 2001).

It should also be noted that, although integrin receptors are recognized as the major class of cell adhesion receptors to extracellular matrix, some studies have shown that other, non-integrin receptors also take part in this process. For example, heparan sulphate proteoglycan on osteoblasts has been found to recognize a bone-specific oligopeptide Lys-Arg-Ser-Arg (KRSR) (Dee et al. 1998). However, the cell-matrix adhesion (mediated by non-integrin adhesion receptors) is still not fully understood (Bačáková et al. 2004a).

\section{Materials used or tested for bone implants}

\section{Single-phase materials}

Currently used and tested materials designed for the construction of bone implants and replacements particularly include metallic alloys, ceramics and synthetic polymers. All of these materials have certain advantageous properties, but all of them have been proven to also possess negative characteristics which limit their widespread use. 
Most of the implants currently utilized in bone surgery are metallic alloys containing $\mathrm{Co}, \mathrm{Cr}, \mathrm{Mo}, \mathrm{Ni}$ or Ti. Metals were chosen as suitable materials thanks to their good mechanical properties, e.g., stiffness, which makes them especially suitable for load-bearing implants. However, they do not match the mechanical properties of natural bone, as they are more rigid and weighty. This stimulates remodeling of the surrounding bone tissue by resorption, because the strain or stress imposed on the bone is carried particularly by the stronger implant. Consequently, this phenomenon in the long term causes aseptic loosening of the implant (Wang 2003). Another risk associated with the use of metallic implants is that in the environment of body fluids they undergo corrosion and they release metallic ions which are cytotoxic or immunogenic in higher concentrations (Park and Kim 2003).

By contrast, ceramics are in general highly biocompatible. Some, e.g., hydroxyapatite, are even strongly bioactive and are able to form a direct bond with the bone tissue. However, their major shortcoming is their insufficient elasticity for the use in bone implants, because they are susceptible to cracking and breaking (Billotte 2003). Polymeric materials provide enormous variability in their properties. Currently used polymers are all biocompatible and light, but they are too soft and elastic, and are not able to carry the weight load on their own.

\section{Multi-phase materials (composites)}

Composite materials, by definition, are materials consisting of two or more different constituents at a micro- or macrosize range having a distinct interface separating them. Their major advantage is that they offer a possibility of combining properties of the initial material to engineer a new construct which would have desirable properties distinct from the properties of the original materials. This approach is now widely used in constructing novel biomaterials for bone implants, taking inspiration from natural bone tissue, which is itself a natural composite.

The mechanical properties of the composite material depend not only on the type of combined materials, but also on the volume fraction and shape of the heterogeneities (particles, fibers, whiskers, platelets, etc.), according to which they are classified into certain groups (Lakes 2003). In the field of biomaterials, fiber- or particle-reinforced composites are of special interest. Usually the harder or stronger phase of the composite is discontinuous and forms the reinforcement, and it is embedded in a continuous phase referred to as matrix (Migliaresi and Alexander 2004). This kind of organization of the composite partially follows the hierarchical architecture of natural bone, which is basically a collagen-hydroxyapatite composite (Wang 2003) (Fig. 1A). In the ECM of bone tissue, the collagen type I fibers provide the strength and function as the reinforcement. These fibers are embedded in a matrix made of other proteins or proteoglycans (such as osteocalcin, osteopontin, osteonectin, bone sialoprotein and bone morphogenetic proteins), which play important roles in controlling the function of osteoblasts, as well as bone tissue mineralization (Inanç et al. 2007, Satija et al. 2007, Dadsetan et al. 2008, Marie 2008, Müller et al. 2008). Both fibers and bone matrix are closely associated with the inorganic particulate component of the bone, i.e., crystals of hydroxyapatite and other calcium phosphates, mainly tricalciumphosphate. Therefore, in the construction of so called "bio-inspired" materials for bone implants, materials consisting of a polymer matrix containing a particulate, bioactive component seem to be the natural choice (Wang 2003). Polymer matrix can be further reinforced by fibers that would, similarly as collagen, strengthen the whole construct.

As mentioned above, the performance of the composite materials could be markedly improved if these materials are constructed in the form of three-dimensional scaffolds (Fig. 1B). If these cell carriers are degradable, they can be gradually replaced with regenerated bone tissue. The ingrowth and maturation of cells inside the scaffolds could be significantly stimulated by dynamic cell cultivation in perfusion or rotational bioreactors. In comparison with classical static cell culture systems, these bioreactors ensure a better supply of oxygen and nutrient to the cells, quicker waste removal, and provide the cells with mechanical stimulation, which is beneficial for their differentiation and functioning (Janssen et al. 2006, Buzcynska et al. 2007, Zhao et al. 2007). Similar favorable effects on the bone tissue formation were also induced using an electromagnetic bioreactor (Fassina et al. 2007).

Fibrous component of the composites designed for the bone implantation has often been created from natural and synthetic polymers, bioglass, carbon or combinations of these materials. The natural polymers have usually been represented by collagen (Shih et al. 2006, Venugopal et al. 2008), gelatin (Casper et al. 2007), chitosan (Kong et al. 2005, Bhattarai et al. 2005) or silk fibroin ( $\mathrm{Li}$ et al. 2006). However, their synthetic 
counterparts involved a wide range of degradable and stable polymers, such as polycaprolactone (Wutticharoenmongkol et al. 2007), polylactide, polyglycolide and their copolymers (Kim et al. 2006, Buzcynska et al. 2007, McCullen et al. 2007, Jeong et al. 2008); polyphosphazenes, a class of special inorganicorganic polymers known for high biocompatibility, hightemperature stability, and low-temperature flexibility (Nair et al. 2004); and aliphatic or aromatic polyamides, such as aramid (Baidya et al. 2001, Bačáková et al. 2007c; Balík et al. 2008) (Figs 2C and 2D). Similarly, composites with a carbon or polymer matrix reinforced with carbon fibers (Fig. 2B) have long been considered to be very promising for bone tissue implantation and replacement, due to their excellent mechanical properties as well as biocompatibility (Sagomonyants et al. 2008). However, there has been some concern about the fact that in some in vitro, as well as in vivo studies, they have been shown to release small particles and debris (Lewandowska-Szumiel et al. 1999, Bačáková et al. 2001).

For advanced composites, fibers of nano-sized diameter have usually been applied. For example, bioglass nanofibers, in a polylactide matrix, induced rapid spontaneous formation of a hydroxycarbonate apatite layer in a simulated physiological medium (i.e., with ion concentrations similar to those in the human body plasma), as well as maturation of osteoblasts (Kim et al. 2008). Polymeric nanofibers have been loaded with growth factors, mainly bone morphogenetic proteins ( $\mathrm{Li}$ et al. 2006, Park et al. 2006) or ceramic and carbon nanoparticles in order to increase their bioactivity and mechanical strength. For example, hydroxyapatite nanoparticles or carbon nanotubes were encapsulated inside collagen or polylactide nanofibers without forming lumps on the nanofibre surface (Venugopal et al. 2008, Jeong et al. 2008, McCullen et al. 2007). The carbon nanotubes themselves were also used for reinforcement of synthetic polymers or chitosan. These nanoparticles can resemble nanofibers of collagen and other extracellular proteins of the bone, as well as hydroxyapatite and other inorganic crystals in the bone (Price et al. 2004). As a component of polymeric porous scaffolds for bone tissue engineering, they can form nano-sized irregularities on the pore walls and thus promote the ingrowth of bone cells inside the material (Woo et al. 2003, Tan and Saltzman 2004). In addition, carbon nanotubes can be used for electrical stimulation of osteoblasts, which has been reported to promote their proliferation, differentiation, production of mineralized bone matrix, and thus healing of the damaged bone (Supronowicz et al. 2002, Zanello et al. 2006, for a review, see Bačáková et al. 2008). When released from degradable polymeric scaffolds, carbon nanotubes could be relatively quickly eliminated from the organism by glomerular filtration (McDevitt et al. 2007). On the other hand, there is a considerable risk of immunogenic or even genotoxic, mutagenic and carcinogenic action of carbon nanotubes (Zhu et al. 2007, Herzog et al. 2007, Chou et al. 2008; for a review see Bačáková et al. 2008). Sato and Webster (2004) warn about some of the concerns associated with the use of nano-particles of all kinds in the human body, as they may possibly be released from the implant, and their effect on human health is still unknown.

Similarly to the fibers, the matrix component of the composites in artificial bone replacements has usually been made of natural or synthetic polymers, the latter being degradable or durable. Examples of promising and interesting matrices include gelatin, chitosan, alginate (Ren et al. 2002, Li et al. 2005), hyaluronic acid (Bakos et al. 1999), polylactides and their copolymers with glycolides (Kim et al. 2008, Obata and Kasuga 2008, Pamula et al. 2008), hydrogels based on poly(ethylene glycol), PEG (Dadsetan et al. 2008, Jung et al. 2008) or macroporous hydrogels such as poly(2-hydroxyethylmethacrylate), poly(HEMA) (Lesný et al. 2006), siloxane-based materials (Ren et al. 2002, Bačáková et al. 2007c, Obata and Kasuga 2008) polyetheretherketone, PEEK (Baidya et al. 2001, Sagomonyants et al. 2008), poly (ethylene terephthalate), PET (Zhao et al. 2007), polyurethanes (Fassina et al. 2007), polyamides (Wang et al. 2007), high density polyethylene, HDPE (Homaeigohar et al. 2008) as well as various combinations of these materials, e.g., gelatin-siloxane or chitosan-alginate hybrids (Ren et al. 2002, Li et al. 2005) or siloxane-containing poly-(lactic acid) composites (Obata and Kasuga 2008). Polytetrafluoroethylene (PTFE) has been applied in the form of membranes for stimulation of bone tissue regeneration in oral or craniofacial applications (Lilli et al. 2002, Suzuki et al. 2005). All the above mentioned materials have often been combined with inorganic particles and loaded with bioactive molecules, such as bone morphogenetic protein2 or transforming growth factor beta-1 (Lilli et al. 2002, Wang et al. 2007, Homaeigohar et al. 2008, Jung et al. 2008, Kim et al. 2008, Obata and Kasuga 2008).

As the inorganic particulate component of the "bio-inspired" composites, hydroxyapatite (HAp) 
particles have been widely used. This ceramic material belongs to a large group of calcium phosphates. HAp has several advantage. First of all, it is highly biocompatible and bioactive. It is able to form strong bonds with the bone tissue and conduct bone formation. Modification of the material surface with HAp was shown to be stimulatory for cell proliferation (Vagaská et al. 2006). The underlying mechanism of its high biocompatibility is based upon its ability to adsorb cell adhesive proteins (especially fibronectin and vitronectin) from the serum, which in turn enables osteoblast adhesion through integrin receptors (Kilpadi et al. 2001, Woo et al. 2007).

Recently, with the increasing interest in nanotechnologies, nanoparticles of HAp similar to those in the extracellular matrix are used. This approach has several advantages. First, nanoparticles have the ability to improve the mechanical properties, e.g., to increase the strength of the composite (Kim et al. 2006, Wang et al. 2002, Ramay and Zhang 2004, Huang et al. 2007), especially in porous scaffolds that cannot yet be used in load-bearing implants. In addition, nano-HAp has been proven to have positive effects on cell-biomaterial interactions (Webster et al. 2000). For example, HAp nanoparticles evenly dispersed on the pore walls in a porous chitosan composite enhanced spreading and proliferation of osteoblasts in comparison with scaffolds without HAp (Kong 2005). Similarly, HAp nanoparticles exposed on the surface of poly(lactide-co-glycolide) scaffolds (i.e., not covered by the polymer matrix) increased the cell numbers, level of cell differentiation and matrix mineralization (Kim et al. 2006). Therefore, increased bone tissue formation can be directly related to the contact of osteoblasts with nano-HAp particles. It has been even suggested that the positive effects of HAp nanoparticles on the osteoblast behavior is comparable with the effect of functionalization of ceramics with synthetic RGD sequences (Balasundaram et al. 2006). In general, this implies an immense influence of the nanotopography of new biomaterials.

However, at this point it should also be mentioned that not only the size of the HAp particles, but also their composition, crystallinity and shape are important in order to have a stimulatory effect on the cells. Chou et al. (2005) examined the effect of five different types of apatite particles, which had different effects on the cell viability, proliferation as well as gene expression and differentiation. For example, particles with a less stable crystal structure dissolved more rapidly and caused a local increase of $\mathrm{Ca}^{2+}$ ions in the microenvironment, which induced apoptosis of the seeded osteoblasts. The cells growing on different types of particles showed a different morphology, and in general they had a lower proliferation and adhesion area in comparison with the control cells growing on the tissue culture polystyrene dish, probably due to the microsize of some HAp particles.

Another important member of the calcium phosphate group, used in bone tissue engineering, is tricalcium phosphate (TCP). TCP ceramics have often been preferred over HAp because of their high dissolution rate, which has been reported to facilitate the new bone tissue formation under in vivo conditions, e.g., in experimental mandibular defects in sheep or minipigs (Gatti et al. 1990, Jensen et al. 2007). On the other hand, the higher solubility of TCP can be associated with a higher release and local concentration of calcium and phosphate ions, which can act toxically on the surrounding cells (Yamada et al. 1997, John et al. 2003, Detsch et al. 2008). In our earlier study performed in conventional static cell culture system, adhesion substrates for human osteoblast-like MG63 cells, made of beta-TCP, induced strong alkalization of the cell culture media, followed by cell death (Bačáková et al. 2004b).

In addition to calcium phosphates, other inorganic compounds have been used in order to enhance the bioactivity of artificial supports for bone tissue reconstruction, such as calcium carbonate, silicate, sulphate or oxide (Verne et al. 2005, Guo et al. 2007, Cui et al. 2008, Obata and Kasuga 2008), phosphates, carbonates, silicates and oxides of magnesium, sodium or potassium (Gough et al. 2003, Bačáková et al. 2004b, Ramaswamy et al. 2005, Verne et al. 2005, Sun et al. 2006, Knabe et al. 2008, Ponader et al. 2008) barium sulphate (Ricker et al. 2008) or molecules containing fluorine or zirconium (Ramaswamy et al. 2005). Similarly as the fibers and matrix molecules in the composites, the inorganic particulate component of the material can also be loaded with various growth factors or drugs stimulating bone tissue regeneration (Cui et al. 2008, Ponader et al. 2008).

\section{Conclusions}

Biomaterials constructed for bone replacements have to meet specific requirements for mechanical properties, biocompatibility and bioactivity. They should mimic the hierarchical architecture or chemical composition of the bone. 
Single-phase materials, such as metals, ceramics, and polymers do not posses optimal properties. Metal alloys are too rigid and weighty, metallic ions released are cytotoxic, ceramics are not elastic and crack easily, synthetic polymers are too soft, and are not able to carry the weight load.

Novel multi-phase composite materials, constructed for bone implants, take inspiration from natural bone tissue, which is itself a natural collagenhydroxyapatite composite. Their major advantage is that they offer the possibility to combine properties of the initial materials, in order to engineer a new construct, with desirable properties distinct from the properties of the original materials. The mechanical properties of the composite material depend not only on the type of combined materials, but also on their volume fraction and shape. In bone tissue replacements, fiber- or particlereinforced composites are of special interest. A stronger discontinuous phase of the composite forms the reinforcement that is embedded in a continuous phase referred to as matrix. Both fibers and bone matrix are closely associated with the inorganic particulate component of the bone, i.e. crystals of hydroxyapatite and other calcium phosphates. Calcium phosphates belong to bioactive molecules which have been observed to improve material integration in the organism during bone regeneration. Bioactivity is also connected with nanoroughness of the surfaces, which support protein adsorption and preferential adhesion of certain cell types; often independently of chemical composition. The effect of nanostructures on cell growth is comparable to other highly advanced strategies, such as incorporation of synthetic ligands for cell adhesion receptors (e.g., RGD or KRSR sequences) onto the material surface, construction of three-dimensional materials with a controllable degradation rate, or controlled release of growth factors and drugs from these materials.

\section{Conflict of Interest}

There is no conflict of interest.

\section{Acknowledgements}

This study was supported by the Grant Agency of the Czech Republic (grants No. 106/06/1576 and 106/09/1000) and the Academy of Sciences of the Czech Republic (grant No. KAN400480701). Mrs. Sherryl Ann Vacik, Pangrac \& Associates, Port Aransas, Texas, U.S.A. is gratefully acknowledged for her language revision of the manuscript.

\section{References}

ARIMA Y, IWATA H: Effect of wettability and surface functional groups on protein adsorption and cell adhesion using well-defined mixed self-assembled monolayers. Biomaterials 28: 3074-3082, 2007.

BAČÁKOVÁ L, STARÝ V, KOFROŇOVÁ O, LISÁ V: Polishing and coating carbon fibre-reinforced carbon composites with a carbon-titanium layer enhances adhesion and growth of osteoblast-like MG63 cells and vascular smooth muscle cells in vitro. J Biomed Mater Res 54: 567-578, 2001.

BAČÁKOVÁ L, FILOVÁ E, RYPÁČEK F, ŠVORČÍK V, STARÝ V: Cell adhesion on artificial materials for tissue engineering. Physiol Res 53 (Suppl 1): S35-S45, 2004a.

BAČÁKOVÁ L, JUNGOVÁ I, ŚLÓSARCZYK A, ZIMA A, PASZKIEWICZ Z: Adhesion and growth on human osteoblast-like MG 63 cells in cultures on calcium phosphate-based biomaterials. Inżynieria Biomateriałów (Engineering of Biomaterials) 7 (38-42): 15-18, $2004 \mathrm{~b}$.

BAČÁKOVÁ L, FILOVÁ E, KUBIES D, MACHOVÁ L, PROKS V, MALINOVÁ V, LISÁ V, RYPÁČEK F: Adhesion and growth of vascular smooth muscle cells in cultures on bioactive RGD peptide-carrying polylactides. J Mater Sci Mater Med 18: 1317-1323, 2007a.

BAČÁKOVÁ L, GRAUSOVÁ L, VACÍK J, FRACZEK A, BLAZEWICZ S, KROMKA A, VANĚČEK M, ŠVORČÍK V: Improved adhesion and growth of human osteoblast-like MG 63 cells on biomaterials modified with carbon nanoparticles. Diamond Relat Mater 16: 2133-2140, $2007 \mathrm{~b}$.

BAČÁKOVÁ L, VAGASKÁ B, BALÍK K, SUCHARDA Z, SUCHÝ T, SOCHOR M: Adhesion and growth of human osteoblast-like cells on polyamide-polysiloxane-hydroxyapatite composites. Euromat 2007, Nuremberg, Germany, http://www.euromat2007.fems.org/; 2007c. 
BAČÁKOVÁ L, GRAUSOVÁ L, VANDROVCOVÁ M, VACÍK J, FRAZCEK A, BLAZEWICZ S, KROMKA A, REZEK B, VANĚČEK M, NESLÁDEK M, ŠVORČÍK V., KOPEČEK M: Carbon nanoparticles as substrates for cell adhesion and growth. In: Nanoparticles: New Research. SL LOMBARDI (ed), Nova Science Publishers, Hauppauge, New York, 2008, pp 39-107.

BAIDYA KP, RAMAKRISHNA S, RAHMAN M, RITCHIE A: Quantitative radiographic analysis of fiber reinforced polymer composites. J Biomater Appl 15: 279-289, 2001.

BAKOS D, SOLDÁN M, HERNÁNDEZ-FUENTES I: Hydroxyapatite-collagen-hyaluronic acid composite. Biomaterials 20: 191-195, 1999.

BALASUNDARAM G, SATO M, WEBSTER TJ: Using hydroxyapatite and decreased crystallinity to promote osteoblast adhesion similar to functionalizing with RGD. Biomaterials 27: 2798-2805, 2006.

BALÍK K, SUCHÝ T., SUCHARDA Z., ČERNÝ M., BAČÁKOVÁ L., SOCHOR M., ŠLOUF M: Effect of nano/micro particles of calcium phosphates on the mechanical properties of composites based on polysiloxane matrix reinforced by polyamide. Ceramics-Silikáty 52: 260-267, 2008.

BHATTARAI N, EDMONDSON D, VEISEH O, MATSEN FA, ZHANG M: Electrospun chitosan-based nanofibers and their cellular compatibility. Biomaterials 26: 6176-6184, 2005.

BILlOTTE WG: Ceramic Biomaterials. In: Biomaterials: Principles and Applications. JB PARK, JD BRONZINO (eds), CRC Press, Boca Raton, FL, 2003, pp 21-35.

BOCCACCINI AR, BLAKER JJ: Bioactive composite materials for tissue engineering scaffolds. Expert Rev Med Devices 2: 303-317, 2005.

BUCZYŃSKA J, PAMULA E, BLAŻEWICZ S, BAČÁKOVÁ L, PAŘÍZEK M, CHLUPÁČ J, MIKOLAJCZYK T, BOGUŃ M, DOBRZYŃSKI P: Fibrous scaffolds for bone tissue engineering: static and dynamic in vitro studies with MG63 cells. Inżynieria Biomateriałów (Engineering of Biomaterials), 10 (65-66): 1-6, 2007.

CASPER CL, YANG W, FARACH-CARSON MC, RABOLT JF: Coating electrospun collagen and gelatin fibers with perlecan domain I for increased growth factor binding. Biomacromolecules 8: 1116-1123, 2007.

CHENG SL, LAI CF, BLYSTONE SD, AVIOLI LV: Bone mineralization and osteoblast differentiation are negatively modulated by integrin alpha(v)beta3. J Bone Miner Res 16: 277-288, 2001.

CHOU CC, HSIAO HY, HONG QS, CHEN CH, PENG YW, CHEN HW, YANG PC: Single-walled carbon nanotubes can induce pulmonary injury in mouse model. Nano Lett 8: 437-445, 2008.

CHOU YF, HUANG W, DUNN JCY, MILLER TA, WU BM: The effect of biomimetic apatite structure on osteoblast viability, proliferation, and gene expression. Biomaterials 26: 285-295, 2005.

CLOVER J, DODDS RA, GOWEN M: Integrin subunit expression by human osteblasts and osteoclasts in situ and in culture. J Cell Sci 103: 267-271, 1992.

CUI X, ZHANG B, WANG Y, GAO Y: Effects of chitosan-coated pressed calcium sulfate pellet combined with recombinant human bone morphogenetic protein 2 on restoration of segmental bone defect. J Craniofac Surg 19: 459-465, 2008.

DADSETAN M, HEFFERAN TE, SZATKOWSKI JP, MISHRA PK, MACURA SI, LU L, YASZEMSKI MJ: Effect of hydrogel porosity on marrow stromal cell phenotypic expression. Biomaterials 29: 2193-2202, 2008.

DANEN EHJ, SONNENBERG A: Integrins in regulation of tissue development and function. $J$ Pathol 200: 471-480, 2003.

DEE KC, ANDERSEN TT, BIZIOS R: Design and function of novel osteoblast-adhesive peptides for chemical modifications of biomaterials. J Biomed Mater Res 40: 371-377, 1998.

DETSCH R, MAYR H, ZIEGLER G: Formation of osteoclast-like cells on HA and TCP ceramics. Acta Biomater 4: 139-148, 2008.

ENGLER A, BAČÁKOVÁ L, NEWMAN C, HATEGAN A, GRIFFIN M, DISCHER D: Substrate compliance versus ligand density in cell on gel responses. Biophys $J$ 86: 617-628, 2004.

ENGLER AJ, SEN S, SWEENEY HL, DISCHER DE: Matrix elasticity directs stem cell lineage specification. Cell 126: 677-689, 2006.

FASSINA L, VISAI L, DE ANGELIS MG, BENAZZO F, MAGENES G: Surface modification of a porous polyurethane through a culture of human osteoblasts and an electromagnetic bioreactor. Technol Health Care 15: 33-45, 2007. 
GARCIA JA: Get a grip: integrins in cell-biomaterial interactions. Biomaterials 26: 7525-7529, 2005.

GATTI AM, ZATFE D, POLI GP: Behaviour of tricalcium phosphate and hydroxyapatite granules in sheep bone defects. Biomaterials 11: 513-517, 1990.

GEIGER B, BERSHADSKY A, PANKOV R, YAMADA KM: Transmembrane extracellular matrix-cytoskeleton crosstalk. Nat Rev Mol Cell Biol 2: 793-805, 2001.

GOUGH JE, CHRISTIAN P, SCOTCHFORD CA, JONES IA: Long-term craniofacial osteoblast culture on a sodium phosphate and a calcium/sodium phosphate glass. J Biomed Mater Res A 66: 233-240, 2003.

GRONTHOS S, STEWART K, GRAVES SE, HAY S, SIMMONS PJ: Integrin expression and function on human osteoblast-like cells. J Bone Miner Res 12: 1189-1197, 1997.

GUO H, WEI J, YUAN Y, LIU C: Development of calcium silicate/calcium phosphate cement for bone regeneration. Biomed Mater 2: S153-S159, 2007.

HENCH LL, POLAK JM: Third-generation biomedical materials. Science 295: 1014-1017, 2002.

HERZOG E, CASEY A, LYNG FM, CHAMBERS G, BYRNE HJ, DAVOREN M: A new approach to the toxicity testing of carbon-based nanomaterials - the clonogenic assay. Toxicol Lett 174: 49-60, 2007.

HOMAEIGOHAR SSH, SHOKRGOZAR MA, KHAVANDI A, SADI AY: In vitro biological evaluation of betaTCP/HDPE - A novel orthopedic composite: a survey using human osteoblast and fibroblast bone cells. J Biomed Mater Res A 84: 491-499, 2008.

HORBETT TA: The role of adsorbed proteins in tissue response to biomaterials. In: Biomaterials Science: an Introduction to Materials in Medicine, BD RATNER, AS HOFFMAN, FJ SCHOEN, JE LEMONS (eds), Elsevier Academic Press, Amsterdam, 2004, pp 237-246.

HORTON, MA: The avß3 integrin "vitronectin receptor". Int J Biochem Cell Biol 29: 721-725, 1997.

HUANG YX, REN J, CHEN C, REN TB, ZHOU XY: Preparation and properties of poly(lactide-co-glycolide) (PLGA)/nano-hydroxyapatite (NHA) scaffolds by thermally induced phase separation and rabbit MSCs culture on scaffolds. J Biomater Appl 22: 409-432, 2008.

HYNES RO: Integrins: Bidirectional, allosteric signaling machines. Cell 110: 673-687, 2002.

INANÇ B, ELÇIN AE, ELÇIN YM: Effect of osteogenic induction on the in vitro differentiation of human embryonic stem cells cocultured with periodontal ligament fibroblasts. Artif Organs 31: 792-800, 2007.

JANSSEN FW, OOSTRA J, OORSCHOT A, VAN BLITTERSWIJK CA: A perfusion bioreactor system capable of producing clinically relevant volumes of tissue-engineered bone: in vivo bone formation showing proof of concept. Biomaterials 27: 315-323, 2006.

JENSEN SS, YEO A, DARD M, HUNZIKER E, SCHENK R, BUSER D: Evaluation of a novel biphasic calcium phosphate in standardized bone defects: a histologic and histomorphometric study in the mandibles of minipigs. Clin Oral Implants Res 18: 752-760, 2007.

JEONG SI, KO EK, YUM J, JUNG CH, LEE YM, SHIN H: Nanofibrous poly(lactic acid)/hydroxyapatite composite scaffolds for guided tissue regeneration. Macromol Biosci 8: 328-338, 2008.

JOHN A, VARMA HK, KUMARI TV: Surface reactivity of calcium phosphate based ceramics in a cell culture system. J Biomater Appl 18: 63-78, 2003.

JUNG RE, WEBER FE, THOMA DS, EHRBAR M, COCHRAN DL, HÄMMERLE CH: Bone morphogenetic protein-2 enhances bone formation when delivered by a synthetic matrix containing hydroxyapatite/tricalciumphosphate. Clin Oral Implants Res 19: 188-195, 2008.

KESELOWSKY BG, COLLARD DM, GARCIA AJ: Surface chemistry modulates fibronectin conformation and directs integrin binding and specificity to control cell adhesion. J Biomed Mater Res A 66: 247-259, 2003.

KESELOWSKY BG, COLLARD DM, GARCIA AJ: Integrin binding specificity regulates biomaterial surface chemistry effects on cell differentiation. Proc Natl Acad Sci USA 102: 5953-5957, 2005.

KILPADI KL, CHANG P, BELLIS SL: Hydroxylapatite binds more serum proteins, purified integrins, and osteoblast precursor cells than titanium or steel. J Biomed Mater Res 57: 258-267, 2001.

KIM S, KIM SS, LEE SH, EUN AHN S, GWAK SJ, SONG JH, KIM BS, CHUNG HM: In vivo bone formation from human embryonic stem cell-derived osteogenic cells in poly(d,l-lactic-co-glycolic acid)/hydroxyapatite composite scaffolds. Biomaterials 29: 1043-1053, 2008. 
KIM SS, PARK MS, JEON O, CHOI CY, KIM BS: Poly(lactide-co-glycolide)/hydroxyapatite scaffolds for bone tissue engineering. Biomaterials 27: 1399-1409, 2006.

KNABE C, HOUSHMAND A, BERGER G, DUCHEYNE P, GILDENHAAR R, KRANZ I, STILLER M: Effect of rapidly resorbable bone substitute materials on the temporal expression of the osteoblastic phenotype in vitro. J Biomed Mater Res A 84: 856-868, 2008.

KONG L, GAO Y, CAO W, GONG Y, ZHAO N, ZHANG X: Preparation and characterization of nanohydroxyapatite/chitosan composite scaffolds. J Biomed Mater Res A 75: 275-282, 2005.

LAI CF, CHENG SL: $\alpha \mathrm{v} \beta$ integrins play an essential role in BMP-2 induction of osteoblast differentiation. $J$ Bone Miner Res 20: 330-340, 2005.

LAKES RS: Composite Biomaterials. In: Biomaterials: Principles and Applications. JB PARK, JD BRONZINO (eds), CRC Press, Boca Raton, FL, 2003, pp 79-80.

LEE JH, LEE JW, KHANG G, LEE HB: Interaction of cells on chargeable functional group gradient surfaces. Biomaterials 18: 351-358, 1997.

LESNÝ P, PŘÁDNÝ M, JENDELOVÁ P, MICHÁLEK J, VACÍK J, SYKOVÁ E: Macroporous hydrogels based on 2-hydroxyethyl methacrylate. Part 4. Growth of rat bone marrow stromal cells in three-dimensional hydrogels with positive and negative surface charges and in polyelectrolyte complexes. J Mater Sci Mater Med 17: 829$833,2006$.

LEWANDOWSKA-SZUMIEL M, KOMENDER J, CHLOPEK J: Interaction between carbon composites and bone after intrabone implantation. J Biomed Mater Res (Appl Biomater) 48: 289-296, 1999.

LI C, VEPARI C, JIN HJ, KIM HJ, KAPLAN DL: Electrospun silk-BMP-2 scaffolds for bone tissue engineering. Biomaterials 27: 3115-3124, 2006.

LI Z, RAMAY HR, HAUCH KD, XIAO D, ZHANG M: Chitosan-alginate hybrid scaffolds for bone tissue engineering. Biomaterials 26: 3919-3928, 2005.

LILLI C, MARINUCCI L, STABELLINI G, BELCASTRO S, BECCHETTI E, BALDUCCI C, STAFFOLANI N, LOCCI P: Biomembranes enriched with TGFbetal favor bone matrix protein expression by human osteoblasts in vitro. J Biomed Mater Res 63: 577-582, 2002.

LOSSDORFER S, SCHWARTZ Z, WANG L, LOHMAN CH, TURNER JD, WIELAND M, COCHRAN DL, BOYAN BD: Microrough implant surface topographies increase osteogenesis by reducing osteoclast formation and activity. J Biomed Mat Res A 70: 361-369, 2004.

MARIE PJ: Transcription factors controlling osteoblastogenesis. Arch Biochem Biophys 473: 98-105, 2008.

MATA A, BOEHM C, FLEISCHMAN AJ, MUSCHLER G, ROY S: Growth of connective tissue progenitor cells on microtextured polydimethylsiloxane surfaces. J Biomed Mater Res 62: 499-506, 2002.

MCCULlEN SD, STEVENS DR, ROBERTS WA, CLARKE LI, BERNACKI SH, GORGA RE, LOBOA EG: Characterization of electrospun nanocomposite scaffolds and biocompatibility with adipose-derived human mesenchymal stem cells. Int J Nanomedicine 2: 253-263, 2007.

MCDEVITT MR, CHATTOPADHYAY D, JAGGI JS, FINN RD, ZANZONICO PB, VILLA C, REY D, MENDENHALL J, BATT CA, NJARDARSON JT, SCHEINBERG DA: PET imaging of soluble yttrium-86labeled carbon nanotubes in mice. PLoS ONE 2: e907, 2007.

MIGLIARESI C, ALEXANDER H: Composites. In: Biomaterials Science: An Introduction to Materials in Medicine, BD RATNER, AS HOFFMAN, FJ SCHOEN, JE LEMONS (eds), Elsevier Academic Press, Amsterdam, 2004, pp 181-184.

MÜLLER B, PRANTE C, GASTENS M, KUHN J, KLEESIEK K, GÖTTING C: Increased levels of xylosyltransferase I correlate with the mineralization of the extracellular matrix during osteogenic differentiation of mesenchymal stem cells. Matrix Biol 27: 139-149, 2008.

NAIR LS, BHATTACHARYYA S, BENDER JD, GREISH YE, BROWN PW, ALLCOCK HR, LAURENCIN CT: Fabrication and optimization of methylphenoxy substituted polyphosphazene nanofibers for biomedical applications. Biomacromolecules 5: 2212-2220, 2004.

OBATA A, KASUGA T: Cellular compatibility of bone-like apatite containing silicon species. $J$ Biomed Mater Res $A$ 85: 140-144, 2008. 
PAMULA E, BAČÁKOVÁ L, FILOVA E, BUCZYNSKA J, DOBRZYNSKI P, NOSKOVA L, GRAUSOVA L: The influence of pore size on colonization of poly(L-lactide-glycolide) scaffolds with human osteoblast-like MG 63 cells in vitro. J Mater Sci Mater Med 19: 425-435, 2008.

PARK JB, BRONZINO JD: Biomaterials: Principles and Applications. CRC Press, Boca Raton, FL, 2003, p IV.

PARK JB, KIM YK: Metallic Biomaterials. In: Biomaterials: Principles and Applications. JB PARK, JD BRONZINO (eds), CRC Press, Boca Raton, FL, 2003, p 5.

PARK YJ, KIM KH, LEE JY, KU Y, LEE SJ, MIN BM, CHUNG CP: Immobilization of bone morphogenetic protein2 on a nanofibrous chitosan membrane for enhanced guided bone regeneration. Biotechnol Appl Biochem 43: 17-24, 2006.

PONADER S, BRANDT H, VAIRAKTARIS E, VON WILMOWSKY C, NKENKE E, SCHLEGEL KA, NEUKAM FW, HOLST S, MÜLLER FA, GREIL P: In vitro response of hFOB cells to pamidronate modified sodium silicate coated cellulose scaffolds. Colloids Surf B Biointerfaces 64: 275-283, 2008.

PRICE RL, ELLISON K, HABERSTROH KM, WEBSTER TJ: Nanometer surface roughness increases select osteoblast adhesion on carbon nanofiber compacts. J Biomed Mater Res A 70: 129-138, 2004.

RAMASWAMY Y, HAYNES DR, BERGER G, GILDENHAAR R, LUCAS H, HOLDING C, ZREIQAT H: Bioceramics composition modulate resorption of human osteoclasts. J Mater Sci Mater Med 16: 1199-1205, 2005.

RAMAY HRR, ZHANG M: Biphasic calcium phosphate nanocomposite porous scaffolds for load-bearing bone tissue engineering. Biomaterials 25: 5171-5180, 2004.

REN L, TSURU K, HAYAKAWA S, OSAKA A: Novel approach to fabricate porous gelatin-siloxane hybrids for bone tissue engineering. Biomaterials 23: 4765-4773, 2002.

REZWAN K, CHEN QZ, BLAKER JJ, BOCCACCINI AR: Biodegradable and bioactive porous polymer/inorganic composite scaffolds for bone tissue engineering. Biomaterials 27: 3413-3431, 2006.

RICKER A, LIU-SNYDER P, WEBSTER TJ: The influence of nano MgO and BaSO4 particle size additives on properties of PMMA bone cement. Int J Nanomedicine 3: 125-132, 2008.

SAGOMONYANTS KB, JARMAN-SMITH ML, DEVINE JN, ARONOW MS, GRONOWICZ GA: The in vitro response of human osteoblasts to polyetheretherketone (PEEK) substrates compared to commercially pure titanium. Biomaterials 29: 1563-1572, 2008.

SATIJA NK, GURUDUTTA GU, SHARMA S, AFRIN F, GUPTA P, VERMA YK, SINGH VK, TRIPATHI RP: Mesenchymal stem cells: molecular targets for tissue engineering. Stem Cells Dev 16: 7-23, 2007.

SATO M, WEBSTER TJ: Nanobiotechnology: implications for the future of nanotechnology in orthopedic applications. Expert Rev Med Devices 1: 105-114, 2004.

SCHNEIDER GB, PERINPANAYAGAM H, CLEGG M, ZAHARIAS R, SEABOLD D, KELLER J, STANFORD C: Implant surface roughness affects osteoblast gene expression. $J$ Dent Res 82: 372-376, 2003.

SCHWARTZ Z, BELL BF, WANG L, ZHAO G, OLIVARES-NAVARRETE R, BOYAN BD: Beta-1 integrins mediate substrate dependent effects of 1alpha,25(OH)2D3 on osteoblasts. J Steroid Biochem Mol Biol 103: 606-609, 2007.

SHIH YR, CHEN CN, TSAI SW, WANG YJ, LEE OK: Growth of mesenchymal stem cells on electrospun type I collagen nanofibers. Stem Cells 24: 2391-2397, 2006.

SUN H, WU C, DAI K, CHANG J, TANG T: Proliferation and osteoblastic differentiation of human bone marrowderived stromal cells on akermanite-bioactive ceramics. Biomaterials 27: 5651-5657, 2006.

SUPRONOWICZ PR, AJAYAN PM, ULLMANN KR, ARULANANDAM BP, METZGER DW, BIZIOS R: Novel current-conducting composite substrates for exposing osteoblasts to alternating current stimulation. $J$ Biomed Mater Res 59: 499-506, 2002.

SUZUKI S, GRØNDAHL L, LEAVESLEY D, WENTRUP-BYRNE E. In vitro bioactivity of MOEP grafted ePTFE membranes for craniofacial applications. Biomaterials 26: 5303-5312, 2005.

TAN J, SALTZMAN WM: Biomaterials with hierarchically defined micro- and nanoscale structure. Biomaterials 25 : 3593-3601, 2004. 
THOMAS CH, MCFARLAND CD, JENKINS ML, REZANIA A, STEELE JG, HEALY KE: The role of vitronectin in the attachment and spatial distribution of bone derived cells on materials with patterned surface chemistry. J Biomed Mater Res 37: 81-93, 1997.

VAGASKÁ B, BAČÁKOVÁ L, PAMULA E, LISÁ V, DOBRZYNSKI P: Adhesion and growth of human osteoblastlike cells on aliphatic polyesters with different chemical composition, surface roughness and modification with hydroxyapatite. Inzynieria Biomaterialów (Engineering of Biomaterials) 9 (58-60): 4-7, 2006.

VENUGOPAL J, LOW S, CHOON AT, SAMPATH KUMAR TS, RAMAKRISHNA S: Mineralization of osteoblasts with electrospun collagen/hydroxyapatite nanofibers. J Mater Sci Mater Med 19: 2039-2046, 2008.

VERNÈ E, Di NUNZIO S, BOSETTI M, APPENDINO P, BROVARONE CV, MAINA G, CANNAS M: Surface characterization of silver-doped bioactive glass. Biomaterials 26: 5111-5119, 2005.

WANG M: Developing bioactive composite materials for tissue replacement. Biomaterials 24: 2133-2151, 2003.

WANG X, LI Y, WEI J, DE GROOT K: Development of biomimetic nano-hydroxyapatite/poly(hexamethylene adipamide) composites. Biomaterials 23: 4787-4791, 2002.

WANG H, LI Y, ZUO Y, LI J, MA S, CHENG L: Biocompatibility and osteogenesis of biomimetic nanohydroxyapatite/polyamide composite scaffolds for bone tissue engineering. Biomaterials 22: 3338-3348, 2007.

WEBB K, HLADY V, TRESCO PA: Relative importance of surface wettability and charged functional groups on NIH 3 T3 fibroblast attachment, spreading and cytoskeletal organization. J Biomed Mater Res 41: 422-430, 1998.

WEBSTER TJ, ERGUN C, DOREMUS RH, SIEGEL RW, BIZIOSI R: Specific proteins mediate enhanced osteoblast adhesion on nanophase ceramics. J Biomed Mater Res 51: 475-483, 2000.

WOO KM, CHEN VJ, MA PX: Nano-fibrous scaffolding architecture selectively enhances protein adsorption contributing to cell attachment. J Biomed Mater Res A 67: 531-537, 2003.

WOO KM, SEO J, ZHANG R, MA PX: Suppression of apoptosis by enhanced protein adsorption on polymer/hydroxyapatite composite scaffolds. Biomaterials 16: 2622-2630, 2007.

WUTTICHAROENMONGKOL P, PAVASANT P, SUPAPHOL P: Osteoblastic phenotype expression of MC3T3-E1 cultured on electrospun polycaprolactone fiber mats filled with hydroxyapatite nanoparticles. Biomacromolecules 8: 2602-2610, 2007.

YAMADA S, HEYMANN D, BOULER JM, DACULSI G: Osteoclastic resorption of calcium phosphate ceramics with different hydroxyapatite/beta-tricalcium phosphate ratios. Biomaterials 18: 1037-1041, 1997.

ZANELLO LP, ZHAO B, HU H, HADDON RC: Bone cell proliferation on carbon nanotubes. Nano Lett 6: 562-567, 2006.

ZHAO F, CHELLA R, MA T: Effects of shear stress on 3-D human mesenchymal stem cell construct development in a perfusion bioreactor system: Experiments and hydrodynamic modeling. Biotechnol Bioeng 96: 584-595, 2007.

ZHAO G, ZINGER O, SCHWARTZ Z, WIELAND M, LANDOLT D, BOYAN BD: Osteoblast-like cells are sensitive to submicron-scale surface structure. Clin Oral Impl Res 17: 258-264, 2006.

ZHU L, CHANG DW, DAI L, HONG Y: DNA damage induced by multiwalled carbon nanotubes in mouse embryonic stem cells. Nano Lett 7: 3592-3597, 2007. 